\title{
Article
}

\section{Implementation Analysis of Digitally Pencak Silat Agility Instrument}

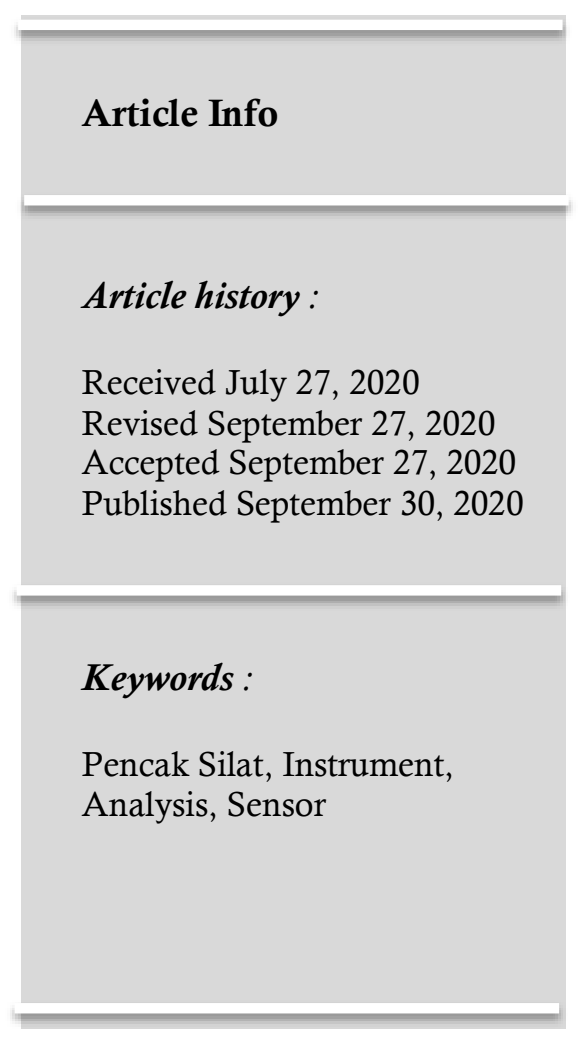

\author{
Januar Sahri*, Nurul Thsan, Bafirman, Asep Sujana Wahyuri \\ Departement of Sport Education, Faculty of Sport Science \\ (FIK), Universitas Negeri Padang, Indonesia
}

\begin{abstract}
This study aims to design an agility test instrument based on sensor technology that is specifically designed to suit the conditions of pencak silat athletes in the field. This research method is Research and Development with the research development steps Borg and Gall. The sample for the small-scale trial was 100 people, while the large-scale trial sample was 120 people. The sample of this study were athletes at Padang State University aged 19-23 years. Based on the development, the resulting tool is a prototype in the form of a rectangular 8 measuring $1 \times 1 \mathrm{M}$ and has 8 sensors in each corner which functions to calculate the number of steps of the athlete's stance which describes his agility. Expert validation shows that the percentage of the assessment is $91 \%$ which means that this measuring instrument has the category of "Good/feasible". Reliability with thetechnique test and retest obtained the $r$ value of small and large group trials for men and women with the "High" category, obtained a practical value of $88.75 \%$, the effectiveness value of $95 \%$. The conclusion is that this instrument is good to use as a measuring tool to measure agility, so this tool is very important as one of the factors supporting the achievements of pencak silat athletes and the development of pencak silat technology in the future.
\end{abstract}

This is an open acces article under the $C C-B Y$ license.

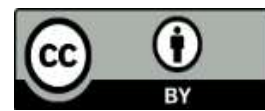

This is an open access article distributed under the Creative Commons 4.0 Attribution License, which permits unrestricted use, distribution, and reproduction in any medium, provided the original work is properly cited. (C2020 by author.

\section{Corresponding Author :}

Januar Sahri

Departement of Sport Education, Faculty of Sport Science (FIK), Universitas Negeri Padang, Indonesia

Email : emizasmeli@gmail.com

\section{Introduction}

Sports achievements are highly contested by all countries in the world, be it the achievements of fighting sports, small balls, big balls and other sports, in developed countries in Europe the 
sports achievements are very advanced compared to Southeast Asia, especially in soccer. ball, all football players in Europe are very well seasoned and supported by sports technology that is growing rapidly, one of the factors supporting athlete's achievement is the availability of technology that supports the development of the physical condition of coaching athletes, developed countries already have various kinds of supporting technology.

Asep Sujana Wahyuri, et al in Mensana Journal (2019)[1] said that "The athlete's performance is not optimal due to many factors such as physical, technical, tactical and mental. The following are some of the physical factors that are referred to: 1 . endurance, 2. strength, 3 . explosive power, 4 . speed, 5 . flexibility, 6 . agility, 7. balance, 8 . coordination, dexterity is needed in an effort to support the performance of athletes of pencak silat and others

Mia Wahyuni Arta and Bafirman in the Satamina Journal (2019)[2], agility is the ability to change direction quickly and precisely. In achieving the achievements of a fighter must master all the elements in pencak silat itself such as elements of physical condition[3], Agility is very important for a fighter, one of Romi Mardela's research results (2019)[4] shows that "Agility training has a significant effect to the improvement of the ability of the crescent kick in pencak silat Kuciang putiah tiger champo" The ability of the crescent kick performed on 16 samples obtained the highest score. 9.38 seconds and the lowest score is 7.18 seconds. Thus, agility training has a significant effect on increasing the ability to kick the sickle.

The instrument is divided into two kinds of tests and non-tests[5]. The purpose of this study is to make a prototype of a test tool that functions to expedite the process of training and measuring the agility of pencak silat athletes so that the use of this tool is to support the progress of the physical condition of the athletes of pencak silat. By developing a prototype, it is hoped that Indonesia can be independent and be able to catch up with sports science and technology so as to spur Indonesia's sports achievements[6]. This dexterity tool has a significant contribution in the world of sports, especially the branch of pencak silat, with the development of this tool, the athlete's training process will run more precisely and programmed, coaches can also easily assess and analyze the weaknesses of athletes that can hinder athlete's performance. In addition, the development of this tool will become a consideration for developers in other sports and can also be an encouragement for other scientists to develop supporting instruments for physical conditions in other sports.

\section{Experimental Section}

Development of measuring instruments (instruments) for the agility of digital technology-based pencak silat athletes requires measurement equipment and electronic components, such as power supplies, imfrared sensors, ATmega328 mocrocontroler and Arduino Uno Rev 3, interfacing and display (LCD) series as digital reading displays that will be assembled and connected using a USB 3.0 cable to produce the output of measurement data in the form of how many sensor bulkheads are trampled correctly at sixteen movements and how many seconds of time the athlete sets foot from sensor one and returns to the bulkhead of sensor one, the researcher made pre-design product devlopment based on the review of related theories and need analysis[7].

At the research stage, it is quite clear that the research stage is carried out, regarding potential problems, researchers make observations and find problems that greatly affect athlete's performance, according to Nurul Ihsan in the sociotechnology journal (2018) [8] saying that in this R\&D research there are several things that are considered by carefully, namely the level of product validity, product practicality, and product effectiveness, but at this stage the researchers began to collect data at the research stage. In the form of qualitative and quantitative data in the form of data from interviews with athletes and coaches as well as historical data on the procurement of supporting instruments for athlete's performance, at the next stage the researcher proposes an instrument design that can solve 
existing problems and perform design validation to related experts such as sports experts, physicists and ergonomic physiology, after validating the design the researchers made revisions based on input from experts, after that the tools began to be worked on and the tools could be tested, in product trials 100 samples were taken with the specifications of 40 female samples and 60 male samples, after doing In the trial, the researcher can see the Weaknesses of the tool that can be overcome, the researcher revises the product to overcome the weaknesses of the tool in the form of system errors and other weaknesses, in the trial using a sample taken as many as 120 samples with specifications of 50 girls and 70 boys. The addition of this sample was carried out to test the robustness of the tool in dealing with larger usage problems. The following is a design and illustration of the use of the dexterity instrument prototype that has been developed:

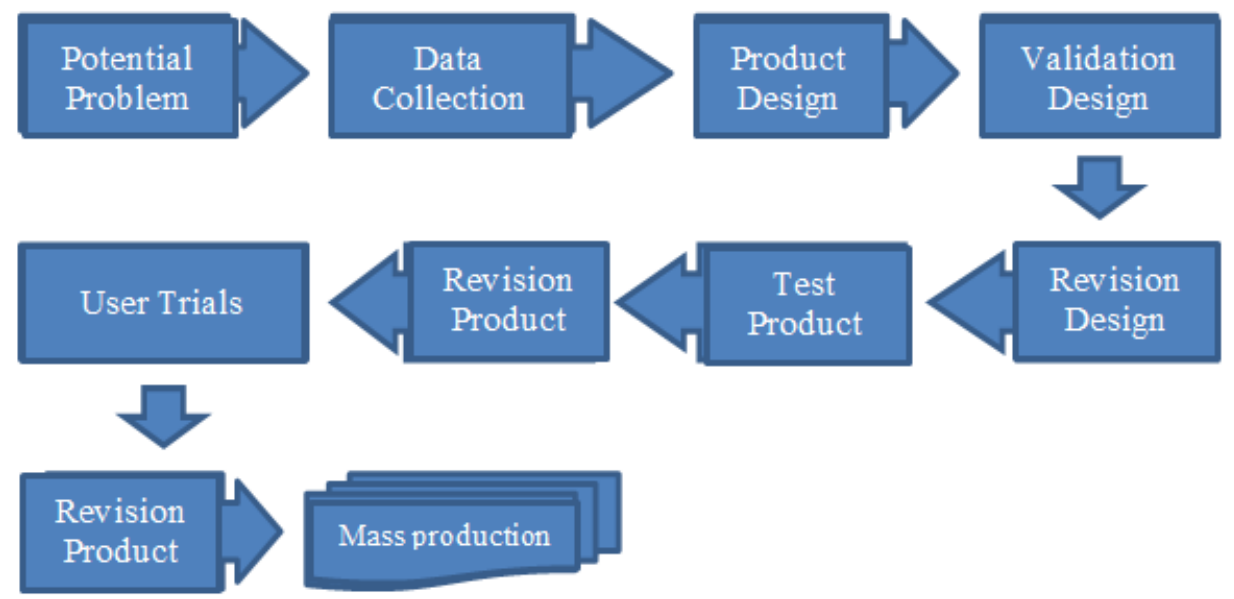

Figure 1. Scheme of research step using Berg and Gail

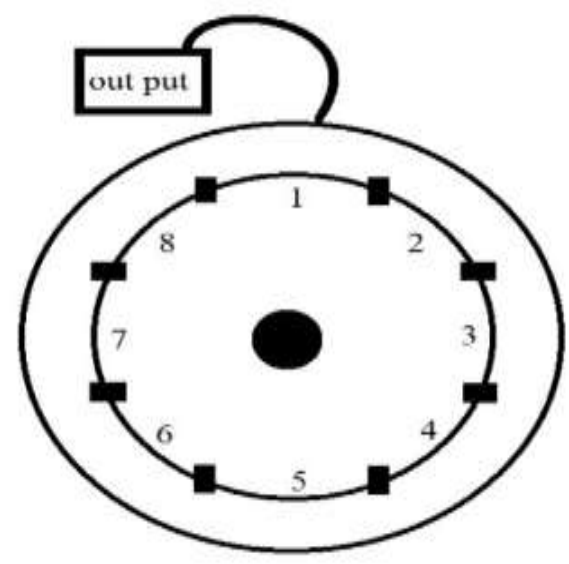

Figure 2. Design of Pecak Silat Instrument 
The instrument has 8 motion sensors that can detect if there is movement across the sensor head, the athlete must demonstrate the front horse movement where the athlete first stands at the center point of the instrument and begins to demonstrate the front horse movement with the right foot stepping to point one and the left foot remaining on the midpoint after that the athlete makes a step movement by doing a backward jump where the right leg that was previously felt returns to the starting point and the left foot which is at the starting point jumps towards the back which is between the center of the point and the fifth sensor after that the right leg jumps towards the second sensor and the left foot returns to the center point and the step movement is carried out again where the right leg changes position again with the left foot and the left foot jumps back, the movement is repeated until the right leg goes to the eighth sensor and the movement returns to the one sensor again, the movement it requires speed of action because of the agility approached $t$ elements of speed, flexibility and balance, in pencak silat the speed of action can be seen with the naked eye or measured [9]. When viewed from an anatomical point of view, the degree of flexibility and agility of the body is determined by several factors, especially the connective tissue in joints, muscles, including ligaments, tendons and the shape of the joint framework, januar sahri (2018)[10].

\section{Results and Discussions \\ Pencak Silat Instrument}

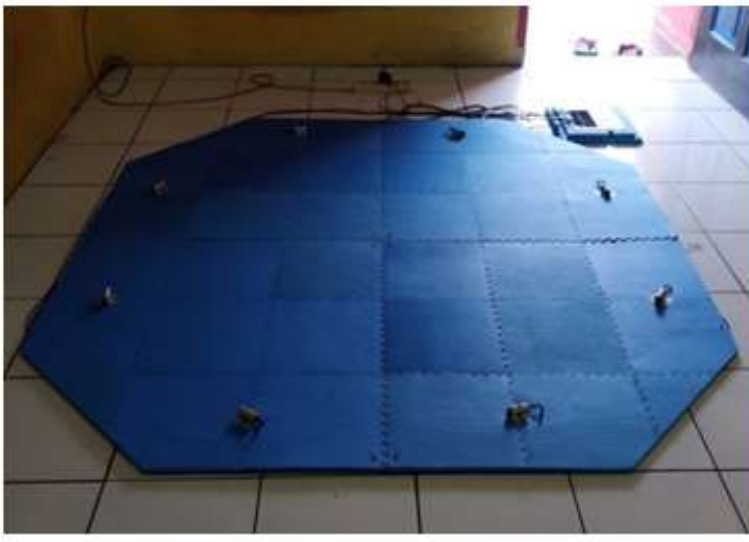

(a)

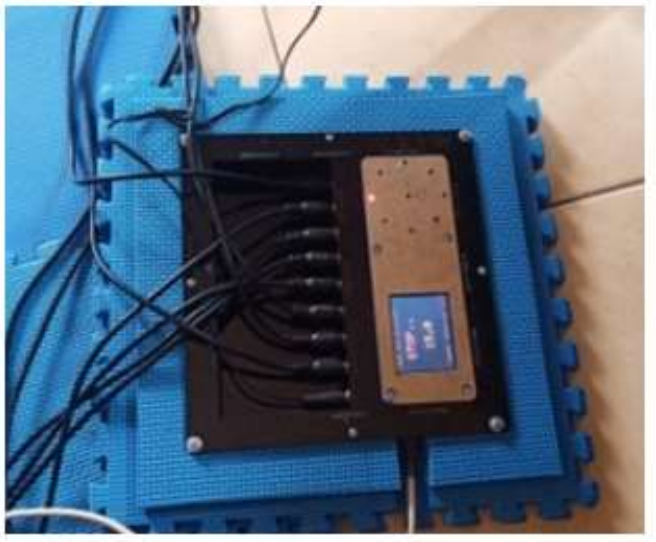

(b)

Figure 3. Pencak Silat Instrument (a) and Sensor for Information (b)

\section{Implementation Analysis}

The result of this research is the availability of prototype instruments for the dexterity of pencak silat athletes that are in accordance with the conditions of athletes in the field and have been tested for the use of their products and have been assessed by experts for both validation and reliability so that they can be used by pencak silat organizations such as IPSI Pusat which is the parent organization. which has derivatives in the Province, Kabupaaten and Kecamatan [14]. 
Test The validity test used is the validity of experts with a questionnaire assessment in order to obtain the validity of $91 \%$ of the category "Very Good / Appropriate". Experts who carry out the assessment consist of four elements of assessment, namely sports physiologists, evaluation and measurement test experts, martial arts experts, and experts. Each IT consists of three experts in each of these elements, so that the total experts involved are 12 experts.

Test of the reliability test for the small male group of 0.997 , the female group to 0.998 and the large group of 0.998 to the male group, the female group to 0.999 with the high reliability and effectiveness category.

The practicality value was $88.75 \%$ and the effectiveness value was $95 \%$. Thus, it can be concluded that the dexterity test tool for digital-based pencak silat athletes is good for use as a measure of agility, this is very important because sport is a sport that really requires agility.

In the research results of Nurhasan (2014) [15] in the journal Unesa, there is a contribution between agility and the ability to kick a sickle by $99.6 \%$, and there is a contribution between agility and speed along with the ability to kick sickle by $99.6 \%$, so it can be said that agility is needed in pencak. martial arts.

Lubis J (2016) [16] an instrument that can be said to be good is an instrument that must have a level of validity and validity that can be proven. Furthermore, according to Saputro DP (2018) [17] a good instrument is one that has a need, namely a high level of validity. Setiawan A (2012) [18] explains that reliability is the consistency value of an instrument.

Measuring the validity and reliability of this tool is intended so that the tool is truly consistent in order to produce a good instrument because according to the research of Soo J (2018) [19] reveals the fact that elite pencak silat athletes have various attack patterns in the form of agile kicks and punches.

Table 1. Correlation Coefficient Category Small and big group reliability

\begin{tabular}{cccc}
\hline $\mathbf{N}$ & Gender & Koofesien korelasi & Realibilitas \\
\hline 60 & Male & 0.997 & Very Strong \\
40 & Fimale & 0.998 & Very Strong \\
70 & Male & 0.998 & Very Strong \\
50 & Fimale & 0.999 & Very Strong
\end{tabular}

From this table, it is known that the reliability level of the tool produced is "High"

Table 2. Presentation and Feasibility of Experts

\begin{tabular}{cccc}
\hline No & Expert & Percentage & Eligibility level \\
\hline 1 & & $93 \%$ & Very Good / Eligible \\
2 & Sport Faal & $91 \%$ & Very Good / Eligible \\
3 & & $91 \%$ & Very Good / Eligible \\
4 & & $90 \%$ & Very Good / Eligible \\
5 & Evaluation and & $95 \%$ & Very Good / Eligible \\
6 & Sport Test & $98 \%$ & Very Good / Eligible \\
7 & Measurment & $95 \%$ & Very Good / Eligible \\
8 & & $95 \%$ & Very Good / Eligible \\
9 & & $90 \%$ & Very Good / Eligible \\
10 & IT & $92 \%$ & Very Good / Eligible
\end{tabular}




\begin{tabular}{llll}
11 & Pencak Silat & $86 \%$ & Very Good / Eligible \\
12 & $86 \%$ & Very Good / Eligible \\
\hline
\end{tabular}

From the results of the validation by the twelve experts, if averaged, the percentage was $91 \%$ "Very Good / Feasible" and it can be concluded that the results of the development of a digitalbased Pencak Silat Athlete Agility test can be used to measure the Agility of Pencak Silat athletes. As for some suggestions and criticisms of the results of the prototype tools made, they are used as materials for further development when they will be mass produced so that these tools can be of economic value and can be used periodically, analysis is carried out by observing the test results with the actual conditions and looking for solutions to problems on tools [20] besides that it also requires a good methodology According to Sukardi (2015) [21], a research method is a person's effort that is carried out systematically following methodological rules, for example systematic, controlled observation and based on existing theories and is strengthened by existing symptoms.

Table 4. Presentation of Practices from Expert Assessments

\begin{tabular}{|c|c|c|c|c|c|}
\hline No & Expert & $f$ & $\mathbf{N}$ & Percentage & Eligibility level \\
\hline 1 & \multirow{3}{*}{ Sport Faal } & 19 & 20 & $95 \%$ & Very Good / Eligible \\
\hline 2 & & 19 & 20 & $95 \%$ & Very Good / Eligible \\
\hline 3 & & 19 & 20 & $95 \%$ & Very Good / Eligible \\
\hline 4 & \multirow{4}{*}{$\begin{array}{c}\text { Evaluation } \\
\text { and Sport } \\
\text { Test } \\
\text { Measurment }\end{array}$} & 12 & 15 & $80 \%$ & Very Good / Eligible \\
\hline 5 & & 19 & 20 & $95 \%$ & Very Good / Eligible \\
\hline 6 & & 19 & 20 & $95 \%$ & Very Good / Eligible \\
\hline 7 & & 19 & 20 & $95 \%$ & Very Good / Eligible \\
\hline 8 & \multirow{3}{*}{ IT } & 19 & 20 & $95 \%$ & Very Good / Eligible \\
\hline 9 & & 16 & 20 & $80 \%$ & Very Good / Eligible \\
\hline 10 & & 16 & 20 & $80 \%$ & Very Good / Eligible \\
\hline 11 & \multirow{2}{*}{ Pencak Silat } & 8 & 10 & $80 \%$ & Very Good / Eligible \\
\hline 12 & & 8 & 10 & $80 \%$ & Very Good / Eligible \\
\hline
\end{tabular}

From the results of the validation by the twelve experts, if the average practicality value is obtained a percentage of $88.75 \%$ and it can be concluded that the results of the development of the digital-based Pencak Silat Athlete Agility test instrument have a practical level of "Very Good / Feasible"

Table 5. Presentation of Effectiveness from Expert Assessments

\begin{tabular}{cccccc}
\hline No & Expert & $\boldsymbol{f}$ & $\mathbf{N}$ & Percentage & Acceptance \\
\hline 1 & & 18 & 20 & $90 \%$ & Very Good / Eligible \\
2 & Sport Faal & 18 & 20 & $90 \%$ & Very Good / Eligible \\
3 & & 18 & 20 & $90 \%$ & Very Good / Eligible \\
4 & Evaluation and & 19 & 20 & $95 \%$ & Very Good / Eligible \\
5 & Sport Test & 20 & 20 & $100 \%$ & Very Good / Eligible \\
\hline
\end{tabular}

http://www.eksakta.ppj.unp.ac.id/index.php/eksakta 


\begin{tabular}{cccccc}
6 & Measurment & 20 & 20 & $100 \%$ & Very Good / Eligible \\
7 & & 20 & 20 & $100 \%$ & Very Good / Eligible \\
8 & & 29 & 30 & $97 \%$ & Very Good / Eligible \\
9 & IT & 29 & 30 & $97 \%$ & Very Good / Eligible \\
10 & & 30 & 30 & $100 \%$ & Very Good / Eligible \\
11 & \multirow{2}{*}{ Pencak Silat } & 18 & 20 & $90 \%$ & Very Good / Eligible \\
12 & & 18 & 20 & $90 \%$ & Very Good / Eligible \\
\hline
\end{tabular}

From the results of the validation by the twelve experts, if the average effectiveness value is $95 \%$, it can be concluded that the results of the development of a digital-based Pencak Silat agility test kit have a value of "Very Level of effectiveness" Good / Feasible ".

From these trials, it was found that the instruments made had gone through the expert judgment stage and it was found that the dexterity instruments of this pencak silat athlete were in the appropriate category and were suitable for use based on the results of historical measurements that had been made.

This trial confirms that the tools made are in accordance with the test and measurement tools besides that we understand that the characteristics of pencak silat, one of which is using agility [22], Widiastuti (2015) [23] Tests and measurements are tools for collecting data. or information about what you want to achieve, it is also hoped that this research can contribute to science, especially the physical education of the sport of pencak silat [24], and also this prototype is expected to be useful as material to help the learning process of pencak silat in higher education. [25].

\section{Conclusions}

The conclusion from the results of this study is the creation of a special pencak silat agility test instrument which has an assessment percentage of $91 \%$, this proves that the prototype in the form of an agility instrument for pencak silat athletes can be said to be useful and has passed the assessment of experts so that the instrument can be an alternative problem solving. availability of martial arts sports technology at Padang State University. This can be interpreted as a sensorbased flexibility measuring instrument in the category of "Good / decent". The results of the calculation of reliability using the test and retest technique obtained the $r$ value of the small group trial of 0.997 for men and 0.998 for women and the large group trial of 0.998 for men and 0.999 for women with the "High" category, obtained a practical value of $88.75 \%$ and a value effectiveness of $95 \%$. Subsequent research is the improvement of this agility test instrument by simplifying the series of components and maximizing measurements with the addition of a capture camera and voice guidance.

\section{Acknowledgement}

This research is a joint research between lecturers and postgraduate students of Sports Education, Faculty of Sport Sciences, State University of Padang, this article has also been presented at the Universiti Teknologi Malaysia in mid-November 2019 besides this research has involved many components, one of which is Faculty officials. Padang State University sports science, all Padang State University pencak silat athletes, experts, and so on, so the researchers would like to thank the Dean of FIK UNP and the Deputy Deans of FIK UNP, the Postgraduate Coordinator of Sports Education and Sports Science FIK UNP, thanks to athletes and trainers of pencak silat Padang State University, the experts involved, and thanks to the Thesis Advisor, Dr. Nurul Ihsan, S.Pd, M.Pd who is also the Deputy Dean III of FIK UNP. 


\section{References}

1. Asep Sujana Wahyuri, Erizal Nurmai, Emral. Pengaruh Latihan Naik Turun Tangga Terhadap Kemampuan Tendangan Dwi Chagi Atlet Taek Won Do Pemusatan Latihan Daerah Sumatera Barat, Jurnal Mensana. 2019; Volume 4, Nomor 1, Mei 2019, ISSN 25276451 (Print), ISSN 2622-0295 (Online)

2. Bafirman dan Mia Wahyuni Arta. Pengaruh latihan kelincahan menggunakan bola terhadap kemampuan dribble atlet bola basket club binuang sakti sijunjung, Jurnal Stamina. 2019; DOI: www.stamina.ppj.unp.ac.id

3. Edwarsyah, Hardiansyah Sefri, Syampurma Hilmainur. Pengaruh Latihan Sirkuit Training Terhadap Kondisi Fisik Atlet Pencak Silat Unit Kegiatan Olahraga Universitas Negeri Padang. Jurnal Penjakora. 2017; Vol. 4 No 1: 51-63

4. Romi Mardela. Pengaruh Latihan Kelincahan Terhadap Kemampuan Tendangan Sabit Atlet Pencak Silat Kuciang Putiah Harimau Campo. Jurnal Patriot PPJ UNJ: Jakarta. 2019

5. Ermawan Susanto. Pengembangan tes keterampilan renang anak usia prasekolah, Jurnal Penelitian dan Evaluasi Pendidikan. 2010; DOI: https://doi.org/10.21831/pep.v14i2.1070 PT Grasindo

6. Feddy setyo dan Sri haryono. Rancang Bangun Alat Ukur Ketinggian Lompatan Dengan Sensor Infra Merah, Jurnal Teknik Elektro. 2011; Vol. 3 No.1 Januari - Juni 2011

7. Ihsan, Nurul. Development of Speed Measurement System for Pencak Silat Kick Based on Sensor Technology. IOP Conf. Series: Materials Science and Engineering. 2017; doi:10.1088/1757-899X/180/1/012171

8. Ihsan, Nurul. Instrumen Kecepatan Tendangan Pencak Silat Berbasis Teknologi. Jurnal Sosioteknologi. 2018; 17(1): 124-131

9. Ihsan, Nurul. Sumbangan Konsentrasi Terhadap Kecepatan Tendangan Pencak Silat. Jurnal Media Ilmu Keolahragaan Indonesia. 2018; 8(1):34-59

10. Januar Sahri. Pengembangan Alat Ukur Kelentukan Berbasis Sensor Ultrasonik. Skripsi. Padang: FIK Universitaas Negeri Padang. 2018

11. Komaini Anton, Januar Sahri, and Didin Tohidin. Pengembangan Instrumen Tes Kelentukan Statis Berbasis Teknologi Sensor, Jurnal Sosioteknologi. 2018; 17(3) 343-349

12. Sugiyono. Metode Penelitian Kuantitatif Kualitatif dan R \& D. Bandung: Alfabeta. 2013

13. Kumaidah E. Penguatan Eksistensi Bangsa malalui Seni Bela Diri Tradisional Pencak Silat. Humanika J Ilm Kaji Hum. 2012; 4(5):23-32

14. Purbojati MM. Penguatan Olahraga Pencak Silat Sebagai Warisan Budaya Nusantara. J Buaya Nusant. 2014; 1(2):141-7

15. Nurhasan. Implementasi Ilmu Pengetahuan dan Teknologi pada prestasi olahraga. Prosiding Seminar Nasional olahraga kesehatan dan prestasi. Surabaya: FK- Unair. 2014

16. Lubis, J dan Wardoyo, H. Buku Ajar Pencak Silat. Edisi ke-3. Jakarta: PT Rajagrafindo Persada. 2016

17. Saputro DP, Siswantoyo S. Penyusun norma tes fisik pencak silatremaja kateogori tanding. J Keolahragaan. 2018; 4(5):23-32

18. Setiawan A. Pencapaian Prestasi Olahraga Melalui Kegiatan Ekstrakulikuler Pencak Silat. J Pelopor Pendidik. 2012; 4(5):23-32

19. Soo J, Woods CT, Arjunan SP, Aziz AR, Ihsan M. Identifying the performance characteristics explanatory of fight outcome in elite Pencak Silat matches. Int J Perform Anal Sport. 2018; 18(6):973-85

20. Sri Haryono dan Feddy Setyo. Jump Power meter sebagai alat pengukur power tungkai, Jurnal media ilmu keolahragaan Indonesia. 2012; Volume 2, Edisi 1, ISSN: 2088-6802 
21. Sukardi. Metodologi penelitian Pendidikan. Jakarta: PT Bumi Aksara. 2015

22. Wilujeng WA. Hubungan Kecepatan Terhadap Kecepatan Tendangan Sabit di SMP Muhammadiyah 2 Surabaya (studi pada siswa ekstrakulikuler pencak silat tapak suci). J Pendidik Olahraga dan Kesehat. 2013; 4(5):23-32

23. Widiastuti. Tes dan Pengukuran Olahraga. Jakarta: PT Raja Grafindo Persada. 2015

24. Widiastuti, Fhitriani I. Pengembangan Model Senam Berbasis Pencak Silat. JPD J Pendidik Dasar. 2017;8(2):51-7

25. Ginanjar nugraheningsih dan Yulius AS. Peningkatan Kesegaran Jasmani Melalui Matakuliah Pencak Silat Mahasiswa Ilmu Keolahragaan. Jurnal Pendidikan Jasmani, Olahraga dan Kesehatan. 2019; 3(1) DOI:https://doi.org/10.33503/jp.jok.v3i1.560 